\title{
An overview of pharmaceutical patent litigation in China
}

\author{
"Courts in China have strict evidential requirements..."
}

First draft submitted: 28 October 2015; Article accepted for publication: 28 October 2015; Published online: 18 February 2016

Keywords: China $\bullet$ enforcement $\bullet$ patent $\bullet$ pharmaceutical

There are three key questions when considering invention patent enforcement (I specify 'invention patent' because Chinese law provides for three types of patent: design patents, utility patents and invention patents [1]. Design patents are akin to Community Registered Designs, protecting the shape or appearance of a product; utility patents are akin to the German utility model, protecting new shapes or structures; invention patents protect new technical inventions. This article focuses on invention patents because they are most relevant to the pharmaceutical industry):

- Can we get an injunction?

- How long will it take, and are interim injunctions available?

- Can we recover damages for past infringement?

Before I answer these questions, I will provide a summary overview of the Chinese legal system as it pertains to pharmaceutical patent enforcement. The Patent Law of the People's Republic of China sets out three options when enforcing a patent: civil litigation (akin to a UK court action), administrative action (sui generis and governed by the Measures for Patent Administrative Law Enforcement. The local Intellectual Property Office can impose injunctions and fines on companies selling infringing products) and criminal (very rarely used). Civil litigation is the primary enforce- ment means, but is often used in conjunction with administrative actions for reasons I will explain below. A civil litigation case will typically only take a matter of months from filing the case until a hearing, and generally will result in an injunction being ordered in pharmaceutical cases because the generic product is identical and there can be little dispute about infringement.

That sounds great: a few months and then an injunction. However, the path does not always run so smooth. The first problem is obtaining evidence of infringement. Courts in China have strict evidential requirements [2], and will want to see a statement from a Chinese notary public corroborating an invoice chopped (sealed with a company stamp) by the defendant company for the sample purchase (i.e., the notary public witnessed the investigator purchase the products from the defendant's premises). This evidence can be hard to obtain. Only licensed distributors or hospitals are legally permitted to purchase pharmaceuticals, and companies generally do not require payment (and therefore do not give an invoice) for samples. An experienced investigator will usually be able to surmount these problems but it might take a few months. This therefore adds time to your enforcement timeline. Occasionally the investigator will fail to obtain the evidence, usually because the target company is aware that it is being targeted and is therefore being cautious and selling only to established contacts rather than new contacts. This is

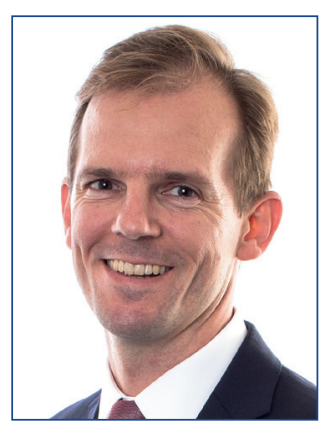

Tom Carver

JA Kemp, London, UK tcarver@jakemp.com 
when the administrative action can be useful. Administrative actions are prosecuted by the local Administration of Industry and Commerce or Intellectual Property Office. These entities are able to raid premises of suspected infringing companies and to seize evidence [3]. If an investigator cannot obtain a sample purchase then the local Administration of Industry and Commerce or Intellectual Property Office might, not guaranteed, be persuaded to visit the premises to gather evidence of manufacture of infringing product, plus product in stock. This evidence can then be used in civil litigation, in lieu of the notary public's statement.

The case is filed (by way of basic pleadings) at the Case Acceptance Division and, assuming it is accepted, will be listed for a trial within 4 or 5 months. No further documents or arguments are filed until the evidence exchange hearing, which is often held the same day as the hearing of the trial.

In the course of the litigation the lead judge will usually try to broker a settlement between the parties. Often it will be in the patentee's interest to agree a settlement, the pragmatic reason being that a defendant is more likely to comply with terms it has agreed than with an order issued by the court.

\section{"Often it will be in the patentee's interest to agree a settlement..."}

Should parties fail to agree then it is up to the court to issue a decision. This can take anything from a few weeks to a year or more, depending on how busy the judge is. A problem for foreign claimants is that Chinese procedural law provides that the court must issue decisions in domestic disputes (i.e., between two Chinese Companies) within a fixed time period, with no equivalent deadline for cases involving foreign parties [4]. This means a busy judge struggling to keep on top of his or her workload might not deal with a foreign claimant's case as a matter of urgency.

Once the decision has been handed down the losing party has 15 days to appeal, with the appeal available as of right. No new evidence nor arguments are permitted in the appeal and it will be heard within 6 months or so, with any order given by the court of first instance (i.e., for an injunction, delivery up/destruction or damages) stayed in the meantime. Again, the judge will explore settlement options with the parties and might take a while to hand down a final decision confirming or overturning the first instance.

I now turn to a few specific items.

\section{Interim injunctions}

These are available in theory but in practice very rarely granted because the claimant is almost always unable to prove that it will suffer irreparable harm if the interim injunction is not granted. Judicial opinion is that the claimant will suffer only monetary harm, and that is not irreparable because damages will be granted if the claimant succeeds at trial (however, see the usual quantum of damages awards, below). There have been two notable recent cases. First, Novartis obtained an interim injunction preventing the sale of imatinib (Glivec ${ }^{\circledR}$, Basel, Switzerland) for the treatment of gastrointestinal stromal tumors, a second medical use [5]. Second, Eli Lilly (IN, USA) obtained an interim injunction in a trade secret case [6], to prevent the further dissemination of stolen confidential information. While both these decisions are very welcome and encouraging, you will note that neither were for a 'vanilla' product patent.

\section{Bifurcated proceedings}

Validity is dealt with by the Patent Re-examination Board. Infringement actions for invention patents will not usually be stayed pending the result of an invalidity attack but patentees should be aware that it is not beyond the realms of possibility, and the Chinese requirements for enablement and sufficiency of pharmaceutical patents make revocation a real risk.

\section{Forum shopping}

Claimants are sometimes tempted to obtain a trap purchase not from the factory (which will usually be out in the provinces with a potentially unreliable local court) but from a trade fair or by other means in the jurisdiction of a more reliable court (i.e., Shanghai, Beijing or Shenzhen). This temptation should be resisted. In my experience the defendant will almost always challenge the jurisdiction of the court, potentially adding a year to the timeline, and even if the challenge fails it may be difficult to enforce an order issued by a court in jurisdiction $\mathrm{A}$ against a defendant in jurisdiction $\mathrm{B}$ [7].

\section{New intellectual property courts}

The lack of consistency between provinces and indeed between cities in the same province has prompted the government to introduce specialist intellectual property courts in Beijing, Shanghai and Guangzhou. It is too early to say how well they are working (they were introduced at the end of 2014) but the plan is to roll them out across the country if they are a success.

\section{Patent linkage}

China operates a patent linkage system, with applicants to the State Food and Drug Administration (SFDA) for new drug approvals being required to provide information on relevant patents together with a statement of noninfringement [8]. Applicants may 
apply up to 2 years prior to the expiry of the patent, but the SFDA should grant approval for the drug only on expiry of relevant patents. However, the database of patents is not accurately maintained and as a result generic companies are hindered from providing full information to the SFDA. The SFDA itself does not have the resources to maintain the database nor investigate the drug approval applications fully and the system therefore does not function as effectively as it might.

Returning, then, to my opening questions:

- Yes, a patentee can obtain an injunction;

- If the defendant agrees to settle then perhaps the matter will only take a few months, depending on how long it took to collect evidence. If the defendant fights then it could take a couple of years for the case to reach final resolution. Interim injunctions are occasionally available;

\section{References}

1 Patent Law of the People's Republic of China. Article 2. http://english.sipo.gov.cn

2 Civil Procedure Law of the People's Republic of China. Article 69. http://en.pkulaw.cn

3 Measures for Patent Administrative Law Enforcement. Article 40.

http://en.pkulaw.cn

4 Civil Procedure Law of the People's Republic of China. Article 270, Article 149 \& Article 176.

http://en.pkulaw.cn
- Damages are available, but not to the extent that claimants might like. In theory the patentee can claim for its loss or the defendant's profit. In practice it is very difficult to provide evidence acceptable to a Chinese court to prove either of those sums. Instead the court will usually award statutory damages of around RMB 200,000 (around GB£20,000) per patent (a maximum of RMB 1,000,000 [around $\mathrm{GB} £ 100,000]$ is possible but unusual) found to be infringed (from personal experience; [9]).

\section{Financial \& competing interests disclosure}

The author has no relevant affiliations or financial involvement with any organization or entity with a financial interest in or financial conflict with the subject matter or materials discussed in the manuscript. This includes employment, consultancies, honoraria, stock ownership or options, expert testimony, grants or patents received or pending, or royalties.

No writing assistance was utilized in the production of this manuscript.

5 Er Zhong Min Bao Zi no. 07639 (2014).

6 Hu Yi Zhong Min Wu (Zhi) Chu no.119 (2013).

7 Civil Procedure Law of the People's Republic of China. Article 127.

http://en.pkulaw.cn

8 Provisions for Drug Registration. Article 18-19. http://eng.sfda.gov.cn

9 CIELA.

www.ciela.cn 